\title{
Physical fitness and aerobic capacity of Polish military fighter aircraft pilots
}

\author{
Andrzej Tomczak, Marcin Haponik \\ Józef Piłsudski University of Physical Education in Warsaw, Faculty in Biała Podlaska, Poland
}

\section{Summary}

Study aim: To determine the level of physical fitness and aerobic capacity of Polish military fighter aircraft pilots. Material and methods: The study was conducted on a group of 120 Polish military fighter aircraft pilots (men). The average age of subject was $37.13 \pm 5.42$ years. For further analysis, the pilots were divided into three age groups: under 29, aged 30-39, and 40-49. Age criteria were adopted according to the classification used by the American Heart Association. A physical fitness test (seven skills) was used to determine the level of physical fitness of pilots. The Åstrand-Ryhming test and a MONARK cycling ergometer were used to determine the level of aerobic capacity.

Results: The pilots obtained the following average results during the physical fitness test: push-ups on a bench -37.7 reps; shuttle run $10 \times 10 \mathrm{~m}-30.3 \mathrm{~s}$; pull-ups -9.1 reps; sit-ups -54 reps; standing long jump $-228.5 \mathrm{~cm}$; zigzag pattern run $-25.8 \mathrm{~s}$; $50 \mathrm{~m}$ swimming $-49.2 \mathrm{~s}$. The physical fitness of military pilots decreases with age. The average level of aerobic capacity of military pilots was estimated at $33.73 \pm 5.62 \mathrm{VO}_{2} \max (\mathrm{ml} / \mathrm{kg} / \mathrm{min})$.

Conclusions: Polish military fighter aircraft pilots are characterized by a medium level of physical fitness and a medium level of aerobic capacity. The level of aerobic capacity is lower currently than 30 years ago. It is a perturbing and negative phenomenon.

Key words: Military pilots - Physical fitness - Aerobic capacity

\section{Introduction}

The level of physical fitness and aerobic capacity largely reflects the condition of health and the ability to undertake various forms of physical activity associated with everyday life, sports or professional activities. Regular physical activity positively affects health and functioning of the body, as it reduces the risk of many lifestyle diseases including diabetes, cardiovascular diseases, and depression $[2,11,15]$.

In some occupational groups, maintaining a high level of physical fitness constitutes a formal requirement. This is associated with the necessity to perform duties in difficult, environmentally diverse conditions, often under psychophysical strain. Air Force pilots constitute one such professional group, and in order to perform tasks in flight, they are required to maintain very good health and a high level of physical fitness and aerobic capacity. Such requirements are justified by the fact that military tasks are performed both while airborne and on the ground [25].
Therefore it is necessary for the pilot to demonstrate a high level of G-tolerance, tolerance of hypoxia, and a high capacity for aerobic physical effort.

Regular measurement of physical fitness and exercise capacity provides information on the readiness of troops to carry out tasks. On the basis of the level of physical fitness and aerobic capacity we can also determine whether the soldiers are injured in some way, or whether there are any symptoms of disease $[17,19]$.

The physical condition of Air Force pilots rests in the care of professionals from the fields of medicine, physical education, nutrition and psychology. In order to regenerate physical strength, restoring health and wellbeing, undergoing emergency and rescue training, familiarizing with what is referred to as life sports, Polish Air Force pilots participate in an obligatory annual physical training course which lasts 3 weeks $[5,21]$.

During the training courses at the training center, Air Force pilots are subjected to fitness tests and the level of their aerobic capacity is evaluated. Physical fitness tests and the assessment of aerobic capacity conducted among 
Air Force pilots vary in different armies [7, 8, 10, 12, 13]. Physical fitness is assessed on the basis of exercises measuring the strength of abdominal muscles and shoulders, speed, agility and running stamina. In some armies, when evaluating physical fitness or aerobic capacity, the waist circumference is also measured to determine the degree of overweight or obesity (e.g., in the USA). Aerobic capacity is generally determined using bicycle ergometer tests $[18,26]$.

The US Army over the years has repeatedly changed the physical exercises by which it evaluates the physical condition of military pilots. It has used, among other things, walking, a 1.5 mile run, and a test on the cycle ergometer. Currently, we can notice a certain similarity in the approach to physical fitness in the Polish Army and in the US Army. In 2004, the US Armed Forces introduced such activities as the 1.5-mile running test, sit ups, and push-ups. It is the focus on physical fitness to be "Fit to Fight" [1].

The aim of the study was to determine the level of physical fitness and aerobic capacity of Polish military fighter aircraft pilots.

\section{Material and methods}

The study was conducted on a group of 120 Polish military fighter aircraft pilots (men) in 2014. The study was conducted at the Military Center of Training and Conditioning at the beginning of the tours, prior to training proper.

The characteristics of the subjects are presented in Table 1 .

Table 1. General characteristics of subjects $(n=120)$

\begin{tabular}{lcc}
\hline Variable & Mean $\pm \mathrm{SD}$ & Range \\
\hline Age [years] & $37.13 \pm 5.42$ & $27.00-49.00$ \\
Body mass $[\mathrm{kg}]$ & $86.57 \pm 10.94$ & $65.00-130.00$ \\
Height $[\mathrm{cm}]$ & $178.65 \pm 5.20$ & $166.00-195.00$ \\
BMI $\left[\mathrm{kg} / \mathrm{m}^{2}\right]$ & $27.12 \pm 3.23$ & $19.84-41.03$ \\
\hline
\end{tabular}

For further analysis, military fighter aircraft pilots were divided into three age groups: under 29 , aged 30-39, and 40-49. Age criteria were adopted according to the classification used by the American Heart Association (AHA) for the assessment of aerobic capacity [2]. The number of subjects in each age group is specified in Table 2. Due to the small number of subjects in the group aged 29 and younger, they were not considered as a separate group in the further analysis.

The obligatory test for Air Force pilots at the Military Center of Training and Conditioning was used to evaluate the general level of physical fitness [16]. The test consisted of seven skill tests, i.e., a zigzag pattern run, $10 \times 10 \mathrm{~m}$ run, pull-ups, push-ups on a bench, 2-minute session of sit-ups, standing long jump and a $50 \mathrm{~m}$ swim.

The Åstrand-Ryhming test and a MONARK $828 \mathrm{E}$ (manufacturer: MONARK EXERCISE AB, Vansbro, Sweden) cycling ergometer were used to determine the aerobic capacity. The test consisted of 5-8 minutes of submaximal exercise (60 rev/min) with constant intensity. The load was selected on the basis of body weight and heart rate (HR). HR was measured using a Polar M 400 pulsometer (manufacturer Polar Electro Oy, Polar Electro Oy, Professorintie 5, FI-90440 KEMPELE, Finland), after each minute of the exercise, which should stabilize in the $130-150$ bpm range. Maximal oxygen consumption was calculated on the basis of the Åstrand nomogram, using the HR value recorded for the last three minutes of effort. The classification of the results of measurement for men is shown in Table 2.

The physical fitness tests and the aerobic capacity tests were conducted separately, on two consecutive days.

\section{Statistical analysis}

Arithmetic mean, standard deviation (SD), ranges of variation, percentage values and medians $(\mathrm{Me})$ were computed. In order to determine the significance of differences between the examined groups, Student's t-test $(\alpha=0.05)$ was used. The statistical program Statistica 6.0 was used.

Table 2. Evaluation of aerobic capacity according to American Heart Association (maximal oxygen consumption) (ml/kg/min) [2]

\begin{tabular}{ccccccc}
\hline & Age [years] & Low capacity & Passable capacity & Average capacity & Good capacity & High capacity \\
\hline & $20-29$ & $<25$ & $25-33$ & $34-42$ & $42-52$ & $>53$ \\
& $30-39$ & $<23$ & $23-30$ & $31-38$ & $39-48$ & $>49$ \\
MEN & $40-49$ & $<20$ & $20-26$ & $27-35$ & $36-44$ & $>45$ \\
& $50-59$ & $<18$ & $18-24$ & $25-33$ & $34-42$ & $>43$ \\
& $60-69$ & $<16$ & $16-22$ & $23-30$ & $31-40$ & $>41$ \\
\hline
\end{tabular}




\section{Results}

\section{Air Force pilots' physical fitness}

Table 3 shows the results of the individual trials in the physical fitness test of all the examined military fighter aircraft pilots. The greatest differences in results were observed in pull-ups, push-ups on a bench and swimming.

The following tables present results for age groups 30-39 and 40-49 (Table 4 and Table 5).

Between the two groups of pilots (aged 30-39 and 40-49), statistically significant differences were noted in the following exercises: push-ups, pull-ups, sit-ups, standing long jump and $50 \mathrm{~m}$ swim. The physical fitness of military fighter aircraft pilots decreases with age.
Table 7 presents the final results of military fighter aircraft pilots in tests of physical fitness by adopting the criteria developed for testing at the Military Center of Training and Conditioning. The arithmetic mean of the marks (results) was 4.26 , indicating a good level of physical condition of the examined Air Force pilots. 2/3 of respondents obtained an overall "good" mark, and almost $1 / 3$ were "very good". Table 8 presents the percentage distribution of the results obtained by military fighter aircraft pilots in the individual exercises. The highest percentage of military fighter aircraft pilots failed the pullup trial $(5 \%)$ and zigzag running $(2.5 \%)$. All military pilots obtained positive marks in push-ups on a bench and standing long jump trials.

Table 3. Results of the physical fitness tests of all tested military fighter aircraft pilots $(\mathrm{n}=120)$

\begin{tabular}{lccccccc}
\hline Variable & $\begin{array}{c}\text { Push-ups on } \\
\text { a bench [number] }\end{array}$ & $\begin{array}{c}\text { Shuttle run } \\
10 \times 10 \mathrm{~m}[\mathrm{~s}]\end{array}$ & $\begin{array}{c}\text { Pull-ups } \\
\text { [number] }\end{array}$ & $\begin{array}{c}2 \text { min of sit-ups } \\
\text { [number] }\end{array}$ & $\begin{array}{c}\text { Standing long } \\
\text { jump [cm] }\end{array}$ & $\begin{array}{c}\text { Zigzag pattern } \\
\text { run [s] }\end{array}$ & $\begin{array}{c}50 \mathrm{~m} \text { swimming } \\
{[\mathrm{s}]}\end{array}$ \\
\hline${ }_{ \pm} \mathrm{SD}$ & $37.7 \pm 10.3$ & $30.3 \pm 1.2$ & $9.1 \pm 3.8$ & $54 \pm 10.3$ & $228.5 \pm 15.3$ & $25.8 \pm 1.4$ & $49.2 \pm 10.9$ \\
Max & 60 & 32.4 & 25 & 80 & 280 & 26.0 & 92.8 \\
Min & 20 & 26.9 & 2 & 25 & 182 & 23.2 & 30.7 \\
Median & 35.0 & 30.3 & 10.0 & 55.0 & 230.0 & 25.5 & 47.9 \\
\hline
\end{tabular}

Table 4. Physical fitness test results of military fighter aircraft pilots aged 30-39 $(n=78)$

\begin{tabular}{lccccccc}
\hline Variable & $\begin{array}{c}\text { Push-ups on } \\
\text { a bench [number] }\end{array}$ & $\begin{array}{c}\text { Shuttle run } \\
10 \times 10 \mathrm{~m}[\mathrm{~s}]\end{array}$ & $\begin{array}{c}\text { Pull-ups } \\
\text { [number] }\end{array}$ & $\begin{array}{c}2 \text { min of sit-ups } \\
\text { [number] }\end{array}$ & $\begin{array}{c}\text { Standing long } \\
\text { jump [cm] }\end{array}$ & $\begin{array}{c}\text { Zigzag pattern } \\
\text { run [s] }\end{array}$ & $\begin{array}{c}50 \mathrm{~m} \text { swimming } \\
{[\mathrm{s}]}\end{array}$ \\
\hline$\pm \mathrm{SD}$ & $41.6 \pm 9.4$ & $30.1 \pm 0.9$ & $9.7 \pm 3.4$ & $57.9 \pm 8.3$ & $232.2 \pm 11.9$ & $25.3 \pm 1.0$ & $46.6 \pm 8.4$ \\
Max & 60 & 31.8 & 16 & 80 & 250 & 26.8 & 65.1 \\
Min & 20 & 27.1 & 2 & 40 & 204 & 24.0 & 30.7 \\
Median & 45 & 30.2 & 10 & 60 & 230 & 25.1 & 47.1 \\
\hline
\end{tabular}

Table 5. Physical fitness test results of military fighter aircraft pilots aged $40-49$ years $(n=37)$

\begin{tabular}{lccccccc}
\hline Variable & $\begin{array}{c}\text { Push-ups on } \\
\text { a bench [number] }\end{array}$ & $\begin{array}{c}\text { Shuttle run } \\
10 \times 10 \mathrm{~m}[\mathrm{~s}]\end{array}$ & $\begin{array}{c}\text { Pull-ups } \\
\text { [number] }\end{array}$ & $\begin{array}{c}2 \text { min of sit-ups } \\
\text { [number] }\end{array}$ & $\begin{array}{c}\text { Standing long } \\
\text { jump [cm] }\end{array}$ & $\begin{array}{c}\text { Zigzag pattern } \\
\text { run [s] }\end{array}$ & $\begin{array}{c}50 \mathrm{~m} \text { swimming } \\
{[\mathrm{s}]}\end{array}$ \\
\hline$\pm \mathrm{SD}$ & $29.2 \pm 7.1$ & $31.6 \pm 1.1$ & $7.3 \pm 4.0$ & $45.2 \pm 8.8$ & $217.9 \pm 15.2$ & $27.0 \pm 1.5$ & $55.2 \pm 13.4$ \\
Max & 60 & 32.4 & 25 & 60 & 240 & 30.2 & 96.8 \\
Min & 20 & 27.7 & 2 & 33 & 182 & 23.7 & 32.6 \\
Median & 30 & 31.2 & 6 & 48 & 220 & 26.8 & 54.1 \\
\hline
\end{tabular}

Table 6. Final results (marks) in the Air Force pilots' physical fitness test $(n=120)$

\begin{tabular}{cccc}
\hline Passable & Acceptable & Good & Very good \\
\hline 0 & $5(4 \%)$ & $79(66 \%)$ & $36(30 \%)$ \\
\hline
\end{tabular}


Table 7. Percentage results of military fighter aircraft pilots $(n=120)$ in each exercise

\begin{tabular}{|c|c|c|c|c|c|c|c|}
\hline Variable & $\begin{array}{l}\text { Push-ups } \\
\text { on a bench } \\
\text { [number] }\end{array}$ & $\begin{array}{l}\text { Shuttle run } \\
10 \times 10 \mathrm{~m}[\mathrm{~s}]\end{array}$ & $\begin{array}{l}\text { Pull-ups } \\
\text { [number] }\end{array}$ & $\begin{array}{c}2 \text { min of sit-ups } \\
\text { [number] }\end{array}$ & $\begin{array}{l}\text { Standing long } \\
\text { jump }[\mathrm{cm}]\end{array}$ & $\begin{array}{l}\text { Zigzag pattern } \\
\text { run }[\mathrm{s}]\end{array}$ & $\begin{array}{c}50 \mathrm{~m} \text { swimming } \\
{[\mathrm{s}]}\end{array}$ \\
\hline 2 & 0 & 6 & 1 & 0 & 1 & 3 & 2 \\
\hline 3 & 10 & 21 & 8 & 8 & 17 & 18 & 16 \\
\hline 4 & 37 & 41 & 36 & 44 & 50 & 41 & 43 \\
\hline 5 & 53 & 32 & 55 & 48 & 32 & 38 & 39 \\
\hline $\begin{array}{l}\% \text { of positive } \\
\text { results (marks) }\end{array}$ & 100 & 95 & 99.2 & 100 & 99.2 & 97.5 & 98.3 \\
\hline
\end{tabular}

Table 8. Level of aerobic capacity of military fighter aircraft pilots in age groups $(n=120)$

\begin{tabular}{|c|c|c|c|c|}
\hline \multirow{2}{*}{ Age group [years] } & \multicolumn{3}{|c|}{$\mathrm{VO}_{2} \max [\mathrm{ml} / \mathrm{kg} / \mathrm{min}]$} & \multirow{2}{*}{$\begin{array}{l}\text { Classification of capacity based on average } \mathrm{VO}_{2} \max \\
\text { according to AHA }[\mathrm{ml} / \mathrm{kg} / \mathrm{min}]\end{array}$} \\
\hline & mean $\pm \mathrm{SD}$ & median & $\min -\max$ & \\
\hline $20-29$ & $33.80 \pm 3.49$ & 32 & $32-40$ & not classified \\
\hline $30-39$ & $34.08 \pm 4.99$ & 35 & $23-44$ & average \\
\hline $40-49$ & $32.97 \pm 7.01$ & 32 & $24-67$ & average \\
\hline Sum/overall & $33.73 \pm 5.62$ & 34 & $23-67$ & - \\
\hline
\end{tabular}

\section{Air Force pilots' aerobic capacity}

Based on the maximal oxygen consumption $\left(\mathrm{VO}_{2} \max \right)$, the Air Force pilots' aerobic capacity was evaluated.

Based on the analysis of the distribution of the body mass index (BMI), conducted in accordance with the classification of the World Health Organization (WHO), it was found that $20 \%$ of the respondents demonstrated normal body mass, $65 \%$ were overweight, and $15 \%$ were obese.

\section{Discussion}

The results of this study indicate that the level of physical fitness of Polish military fighter aircraft pilots is good and the level of aerobic fitness is average. We found a significant difference between results in the individual exercises (trials).

It would be expected that this diversity would be smaller if the military fighter aircraft pilots in terms of physical condition constituted a more homogeneous group, if not in all motor abilities, at least in some of those associated with the strength of the abdominal muscles and lower limbs, considering that they perform similar military tasks. To increase the tolerance of acceleration and correctly perform the L1 straining maneuver, greater strength of the abdominal muscles and lower limbs is required [27]. Unfortunately, in this group of pilots, there was no such relationship. This phenomenon is worrying, because it can be assumed that physical education specialists do not pay attention to such exercises. There does not seem to be sufficient tolerance of overloads [19].

In the literature, there are not many articles which broadly describe the level of physical fitness and/or physical performance of military pilots. Perhaps this is due to the fact that it is commonly believed that a military pilot is an able-bodied man, with high stamina and an athletic figure. Probably when it is worse, steps shall be taken to change this through physical training and dietary changes, but the test results will not be disclosed. In this study we have investigated the broad level of physical fitness of Polish military fighter aircraft pilots. We have compared physical fitness and aerobic fitness of Polish military pilots with soldiers of other formations and other countries.

Based on the criteria of physical fitness developed for Air Force pilots undergoing training in Polish military training centers, it can be assumed that the Air Force pilots' physical fitness level is satisfactory [16]. Below, some raw scores are compared with the results obtained by the soldiers of other specialties.

The military fighter aircraft pilots' physical fitness test results were compared with the results obtained by the soldiers of the special forces unit in the following exercises: sit-ups, pull-ups and $10 \times 10 \mathrm{~m}$ shuttle run [23]. The special forces unit soldiers demonstrated a significantly higher level of physical fitness. Military fighter aircraft pilots performed an average of 54 sit-ups, compared to the 91.5 performed by the special forces unit soldiers $(41 \%$ 
difference). The results in pull-ups were 9.1 and 18.3 respectively $(50.2 \%$ difference), and the $10 \times 10 \mathrm{~m}$ shuttle run times were $30.3 \mathrm{~s}$ and $28.8 \mathrm{~s}$, respectively ( $4.9 \%$ difference).

In the following discussion, the results of physical fitness tests of Air Force pilots will be compared with the results obtained by other soldiers, of all ages (younger). It may seem that the comparison of different age groups is unjustified. In fact, when assessing qualification of soldiers to perform military tasks, one should first and foremost consider their skills, physical fitness and capacity, not their age. A soldier should be prepared to perform specific tasks regardless of age. A similar approach should also be adopted in relation to gender. In a sense, the application, in the military or other uniformed services, of physical fitness tests differentiated according to gender and age seems unfounded. It is particularly unreasonable to use different exercises and standards for women and men in a specific formation [24]. This prompts the question of what purpose such physical fitness tests are to serve.

The physical fitness of Air Force pilots is further compared to conscripts, soldiers and air force officer cadets. Air Force pilots demonstrate significantly better results than mechanized infantry soldiers. In sit-ups, the respective results are 54 to 23.8 repetitions (a $55.9 \%$ difference). Artillery and basic Air Force unit soldiers demonstrated a level of abdominal muscle strength similar to that of mechanized infantry soldiers [22].

Two other studies present the results of the $10 \times 10 \mathrm{~m}$ speed-agility run obtained by Polish Air Force Academy officer cadets, future Air Force pilots. The speed results range from $28.5 \mathrm{~s}$ to $29.30 \mathrm{~s}$ [9,20]. Air force cadets demonstrate higher speed and agility than the tested Air Force pilots.

The levels of aerobic capacity of the examined Air Force pilots will further be compared. First, a comparison will be made with the group of military pilots examined by Klukowski and Kłossowski in the 1970s [6]. A direct comparison is not possible, due to slight differences in the adopted divisions into age groups. In Klukowski and Kłossowski's work, however, in the group aged 28-34, maximal oxygen consumption was at $41.5 \mathrm{ml} / \mathrm{kg} / \mathrm{min}$, and $39.0 \mathrm{ml} / \mathrm{kg} / \mathrm{min}$ in the group aged 35-40. These results can be compared to the current results calculated for the present-day group aged 30-39. The currently tested Air Force pilots demonstrate lower levels of physical fitness. The situation is similar when comparing the two groups from the past study aged $41-44(36.0 \mathrm{ml} / \mathrm{kg} / \mathrm{min})$ and $45-49(34.0 \mathrm{ml} / \mathrm{kg} / \mathrm{min})$ with the present-day group aged $40-49(32.9 \mathrm{ml} / \mathrm{kg} / \mathrm{min})$.

In the study by Tomczak et al., the level of aerobic capacity of the special forces unit soldiers was determined using the Klinge method [23]. The result obtained (57.1 $\mathrm{ml} / \mathrm{kg} / \mathrm{min}$ ) demonstrates that the special forces unit soldiers present a significantly higher level of aerobic capacity than military fighter aircraft pilots. This, undoubtedly, results from the specifics of the tasks performed by special forces soldiers, which demand from them an especially high capacity. Such levels cannot be expected from fighter pilots due to the different task demands and the related psychophysical training [4].

Further in the discussion, the level of aerobic capacity of the examined Air Force pilots was compared with that of foreign armed forces pilots. In the US Air Force, the aerobic capacity is assessed on the basis of the result of maximal oxygen consumption obtained during the submaximal exercise on the cycle ergometer, based on the modification of the Astrand-Ryhming nomogram [18]. Giovannetti evaluated the aerobic capacity of 11305 men serving in the US Air Force two times [1]. First, in 2003 , the aerobic capacity was measured using the modified Astrand and Ryhming test on an ergometer (USAF SCE - submaximal cycle ergometry test). The second test, used in 2005, was the "Fit to Fight" five-mile run. The mean maximal oxygen consumption of the tested men was $35.83 \pm 7.18 \mathrm{ml} / \mathrm{kg} / \mathrm{min}$ in 2003 , which is similar to the result obtained in this work. In 2005, however, it was much better at $41.87 \pm 5.81 \mathrm{ml} / \mathrm{kg} / \mathrm{min}$ [1].

In another work from 1994, soldiers of the US Air Force in a group with an average age of $39.3 \pm 3.9$ years were characterized by average aerobic capacity of $39.9 \pm 9.8$ $\mathrm{ml} / \mathrm{kg} / \mathrm{min}$ in the cycle ergometer test (CET) [26]. In 1999 the aerobic capacity was tested in a group of 8 Royal Australian Air Force pilots. The average result was $50 \pm 6 \mathrm{ml} /$ $\mathrm{kg} / \mathrm{min}$, which translated into a good result in this group of patients [13]. Due to the very small research sample, however, it is not advisable to make comparative analyses with this group.

Nancheva and Minkovski conducted a study of aerobic capacity with a group of 135 men of the Bulgarian Air Force from 18 to 59 years old. The pilots were divided into four age groups. In the group aged from 18 to 25 , the mean maximal oxygen consumption was $2.94 \mathrm{l} / \mathrm{min}(46.15 \mathrm{ml} /$ $\mathrm{kg} / \mathrm{min}$ ), which was the highest value among all the studied groups [12]. In the next age group, from 35 to 40 , the result was $3.03 \mathrm{l} / \mathrm{min}(35.89 \mathrm{ml} / \mathrm{kg} / \mathrm{min})$, which is a value comparable to the result achieved by the pilots examined in the 30-39 age group $(34.08 \pm 4.99 \mathrm{ml} / \mathrm{kg} / \mathrm{min})$. In the group of age 41 to 50 the maximal oxygen consumption was $3.18 \mathrm{l} / \mathrm{min}(39.57 \mathrm{ml} / \mathrm{kg} / \mathrm{min})$. In the present study, a similar age group (40-49) demonstrated an inferior result, equal to $32.97 \pm 7.01 \mathrm{ml} / \mathrm{kg} / \mathrm{min}$. In the group aged over 50, the maximal oxygen consumption observed was $2.78 \mathrm{l} / \mathrm{min}(34.15 \mathrm{ml} / \mathrm{kg} / \mathrm{min})$ [12].

Against the background of the presented literature data, the level of aerobic capacity of Polish Air Force pilots 
corresponds to the lower limits $(33.73 \mathrm{ml} / \mathrm{kg} / \mathrm{min})$ of the results obtained by the Air Force pilots of other countries. According to the AHA criteria, it is evaluated as "good," and as such it is sufficient to allow them to perform duties (in-flight). Analyzing the levels of physical fitness and aerobic capacity of the examined military pilots, it was found that, compared to other groups of soldiers, pilots' physical fitness levels are significantly higher. When aerobic capacity is considered, the pilots' results are lower than those of both the earlier generation of Polish Air Force pilots and the pilots from other countries. This should be a warning sign to take preventative steps against further deterioration of the level of physical fitness. However, caution should be taken in order not to cause adverse effects associated with performing in-flight tasks on jet aircraft. We have to remember that attention to high physical capacity of military pilots is also justified by the fact that the pilot has a higher physical efficiency and greater tolerance of acceleration [17]. Additionally, Oliver-Silva and Boullosa found that there is a significant correlation between exercise capacity, body fatness, state of hydration and the autonomic control of HR during and after flights [14].

In Poland, increased body mass is exhibited by approximately $62 \%$ of men [28]. A similar anomaly was found in the tested military pilots. Two aspects are disturbing. First, military pilots are elite professionals and need to take full care of their health, fitness and physical performance. Second, these are aspects that affect the performance of official duties. The Military Center of Training and Conditioning is a place where military pilots should be made aware. We believe that training camps should be conducted with classes on proper nutrition, carrying out health training, and the ability to maintain the correct body weight. Furthermore, military pilots with significant obesity and overweight should constitute a distinct physical training group and be subject to a special program of physical training. In our research we have found the fundamental reason why the level of physical fitness of Polish military pilots is just medium.

\section{Conclusions}

1. Polish military fighter aircraft pilots are characterized by a good level of physical fitness and an average level of aerobic capacity.

2. Disturbing phenomena are:

- decreasing physical fitness of Polish pilots over several years;

- significant differences in the level of physical fitness of military fighter aircraft pilots.

3. It is necessary for military aviation medicine physicians and physical education specialists to pay attention to this negative phenomenon.

\section{References}

1. Giovannetti J.M., M. Bemben, D. Bemben, J. Cramer (2012) Relationship between estimated aerobic fitness and injury rates among active duty at an Air Force Base based upon two separate measures of estimated cardiovascular fitness. Mil. Med., 177, 1:36, 36-40.

2. Grygiel-Górniak B., A. Tomczak, N. Krulikowska, A. Seraszek-Jarosz, E. Kaczmarek, J. Przysławski (2016) Physical activity, nutritional status, and dietary habits of students of Medical University. Sport Sci. Health, 12(2): 261-267.

3. Jaskólski A., A. Jaskólska (2005) Podstawy fizjologii wysiłku fizycznego z zarysem fizjologii człowieka (Fundamentals of exercise physiology with the outline of human physiology). AWF, Wrocław.

4. Kalina R.M. (2001) Metodologiczne dylematy pomiaru i rozwijania sprawności fizycznej pilota wojskowego (Methodological dilemmas measure and develop physical fitness military pilot). Postępy Medycyny Lotniczej, 2(5): 77-93.

5. Klukowski K. (1992) Pilot wojskowy nie może się obyć bez WOSzK (Military pilot can not do without WOSzK). Przeglad Wojsk Lotniczych i Obrony Powietrznej, 11: 33-35.

6. Klukowski K., M. Kłossowski (1980) Zmiany zdolności wysiłkowej pilotów (Changes in exercise capacity pilots). Przeglad Wojsk Lotniczych i Wojsk Obrony Powietrznej Kraju, 2: 44-49.

7. Klukowski K., M. Kłossowski (1992) Metodyka badań i ocena zdolności wysiłkowej personelu latającego (Research methodology and assessment of exercise capacity crew). Medycyna Lotnicza 3-4 (116-117): 46-55.

8. Kłossowski M., A. Stelęgowski (2004) Ocena związku między masą i składem ciała a sprawnością fizyczną podchorążych Wyższej Szkoły Oficerskiej Sil Powietrznych (The association betweenweight and body composition and physical fitness cadets School Officers Air Force). Pol. J. Aviat. Med., 1(10): 35-38.

9. Kłossowski M., A. Stelęgowski (2012) Zmiany somatyczne, sprawnościowe i wydolnościowe u kandydatów na pilotów samolotów odrzutowych w końcowym okresie studiów I stopnia (Somatic, fitness and anaerobie efficiency changes in the cadet-fighter pilots in the final period of first degree study). Pol. J. Aviat. Med. Psychol., 4(18): 27-36.

10. Knapik J.J., W.B. East (2014) History of United States Army physical fitness and physical readiness training. US Army Med. Dep. J., Apr-Jun: 5-19.

11. Mazzeo R.S., P. Cavanagh, W.J. Evans, M. Fiatarone, J. Hagberg, E. McAuley (1998) Exercise and physical activity for older adults. Med. Sci. Sport Exerc., 30(6): 992-1008. 
12. Nancheva R., L. Minkovski (1994) Physical work capacity of Bulgarian Air Force pilots. Rev. Environ. Health, 10(1): 63-5.

13. Newman D.G., S.W. White, R. Calister (1999) Patterns of physical conditioning in Royal Australian Air Force F/A18 pilots and the implications for $+\mathrm{Gz}$ tolerance. Aviat. Space Environ. Med.,70(8): 739-744.

14. Oliveira-Silva I., D.A. Boullosa (2015) Physical fitness and dehydration influences on the cardiac autonomic control of fighter pilots. Aerosp. Med. Hum. Perform., 2015 Oct; 86(10): 875-880.

15. Paffenbarger R.S., R.T. Hyde, A. Wing, I-M. Lee, D.L. Jung, J.B. Kampert (1993) The association of changes in physical activity level and other lifestyle characteristics with mortality among men. N. Eng. J. Med., 8: 538-545.

16. Ramowy program szkolenia personelu latającego Sił Zbrojnych RP w Wojskowych Ośrodkach Szkolenia Kondycyjnego, Sygn. 393/WLOP, Warszawa 2008 (Programme of staff training flying Armed Forces in Military Conditioning and TrainingCentres, Signature Army Air and Air Defence 393/2008, Warsaw 2008).

17. Rintala H., A. Häkkinen, S. Siitonen, H. Kyrölainem (2015) Relationships between physical fitness, demands of flight duty, and musculoskeleton symptons among military pilots, Mil. Med. 2015 Dec, 180(12):1233-1238.

18. Robbins A.S., S.Y. Chao, V.P. Fonseca, M.R. Snedecor, J.J. Knapik (2001) Predictors of low physical fitness in a cohort of active-duty U.S. Air Force members. Am. J. Prev. Med., 20(2): 90-96.

19. Sovelius R, J. Oksa, H. Rintala, S. Siitonen (2008) Neck and back muscle loading in pilots flying high $\mathrm{G}(\mathrm{z})$ sorties with and without lumbar support. Aviat. Space Environ. Med., 79: 616-619.

20. Stelęgowski A., M. Kłossowski, Z. Wochyński (2011) Wpływ ćwiczeń na lotniczych gimnastycznych przyrządach specjalnych na sprawność motoryczną i skład ciała (The impact of exercise on air gymnastic special devices on motor skills and body composition). Pol. J. Aviat. Med. Psychol., 1: 7-19.

21. Tomczak A. (2006) Trening fizyczny pilotów wojskowych w wojskowych ośrodkach szkoleniowo-kondycyjnych
(Physical training military pilots in military conditioning and training centers). W: A. Chodała, J. Klimczak, A. Rakowski (red.) Trening militarny żołnierzy (Military training of soldiers), Wyższa Szkoła Policji w Szczytnie, Polskie Towarzystwo Naukowe Kultury Fizycznej, t. 10, 161-164.

22. Tomczak A., J. Bertrandt, A. Kłos (2012) Physical fitness and nutritional status of polish ground force units recruits. Biol. Sport, 29: 277-280.

23. Tomczak A., J. Bertrandt, A. Kłos, B. Bertrandt (2014) Assessment ofphysical fitness, physical capacityandnutritional status ofsoldiers serving in the Polish Special Forces unit "GROM". Probl. Hig. Epidemiol., 95(1): $86-90$.

24. Tomczak A., J. Bertrandt, A. Kłos, W. Szymańska, W. Stankiewicz (2016) Effect of the 3-year education in the Main School of Fire Service on the fitness level of students. The manuscript have qualified to Annals of Agricultural and Environmental Medicine.

25. Tomczak A., R.M. Kalina (2007) Appraisal of soldiers` acquired skills for surviving in conditions of isolation. In: M. Sokołowski (eds.) Morphofunctional aspects of selection of soldiers for realization of tasks in the army formations. Polish Scientific Physical Education Association, Warsaw, vol. 11, 84-100.

26. Williford H.N., K. Sport, N. Wang, M.S. Olson, D. Blessing (1994) The prediction of fitness levels of United States Air Force officers: validation of cycle ergometry. Mil. Med., 159(3): 175-178.

27. Wojtkowiak M. (2015) Polish studies on human and animal tolerance to acceleration. Pol. J. Aviat. Med. Psychol., 21(4): 21-33.

28. www.google.pl/?gws_rd=ssl\#q $=$ raport+GUS+2015++na dwaga $+\mathrm{i}+$ oty $\% \mathrm{C} 5 \% 820 \% \mathrm{C} 5 \% 9 \mathrm{~B} \% \mathrm{C} 4 \% 87$ (6.07.2016)

\section{Received 12.05.2016 \\ Accepted 30.09.2016}

(C) University of Physical Education, Warsaw, Poland 